\title{
A COVID-19-fertőzés gastrointestinalis hatásai gyermekkorban és a gyulladásos bélbeteg gyermekekben
}

\author{
Tóbi Luca dr. - Prehoda Bence dr. - Balogh Anna dr. \\ Dezsőfi-Gottl Antal dr. - Cseh Áron dr.
}

Semmelweis Egyetem, Általános Orvostudományi Kar, I. Gyermekgyógyászati Klinika, Budapest

\begin{abstract}
A SARS-CoV-2-infekció változatos kórlefolyású, a gyermekpopulációban növekvő incidenciát mutató fertőzés. Ebben a korcsoportban a felnőttekkel szemben sokkal gyakrabban tapasztalhatók gasztroenterológiai tünetek a betegség során, 18-32\%-ban jelentkezik legalább egy szimptóma. Ezek nem specifikusak, gyakran megegyezhetnek a virális enteritisek, a gyulladásos bélbetegségek vagy a vakbélgyulladás tüneteivel. A gyermekkori SARS-CoV-2-infekciónak egy viszonylag ritkán megjelenő, de súlyos, akár életveszélyes szövődménye a gyermekkori sokszervi gyulladásos szindróma (multisystem inflammatory syndrome in children, MIS-C). Ilyenkor a gastrointestinalis tünetek gyakorisága 60-100\%-ra nő, sok esetben akut has benyomását keltve. A jelenlegi kutatások eredményei alapján a gyulladásos bélbeteg gyerekek az alapbetegségük miatt nincsenek nagyobb veszélynek kitéve az átlagpopulációhoz képest a COVID-19-fertőzés szempontjából. A terápiájukban alkalmazott gyógyszereik közül a nagy dózisú szteroidkezelés okoz nagyobb kockázatot a megfertőződésre, illetve ebben az esetben a súlyosabb kórlefolyásra. Az éppen remisszióban lévő gyulladásos bélbetegek fenntartó terápiájának módosítások nélküli folytatása javasolt, kiemelt figyelmet fordítva a biológiai terápiák időben történő, megszakítás nélküli alkalmazására. Törekedni kell a személyes vizitek számának csökkentésére a pandémia idején, ezek telemedicinával történő helyettesítése javasolt. A halasztható endoszkópos vizsgálatok noninvazív vizsgálómódszerekkel történő átmeneti kiváltása részesítendő előnyben a betegség aktivitásának, a terápia hatékonyságának megítélésére. A gyulladásos bélbetegségben szenvedő gyermekek COVID-19 elleni védőoltása javasolt, jelenleg minden elérhető oltóanyag alkalmazható náluk (az élő ágenst tartalmazó vakcinák ellenjavalltak). Immunmoduláns, szteroid- vagy anti-tumornekrózisfaktor (TNF)-alfa-terápia esetén az oltás lehetséges csökkent hatékonyságával kell számolni.
\end{abstract}

Orv Hetil. 2022; 163(6): 214-221.

Kulcsszavak: COVID-19, IBD, gastrointestinalis, gyulladásos bélbetegség, koronavírus

\section{The gastrointestinal effects of COVID-19 infection during childhood and among the children affected with inflammatory bowel disease}

The SARS-CoV-2 infection is showing high variety in the disease course, with a constantly increasing incidence among the pediatric population. In this age group, at least one gastrointestinal symptom appears in $18-32 \%$ of the cases, showing a significant difference compared to the adult population. The gastrointestinal signs of COVID-19 are not specific, can mimic the symptoms of viral enteritis, inflammatory bowel diseases or acute appendicitis. The multisystem inflammatory syndrome in children (MIS-C) is a rather rare, but serious complication of the pediatric COVID-19 disease: in these cases, the incidence of the gastrointestinal symptoms is increased up to $60-100 \%$, often observed as acute abdomen. Based on recent researches, patients with inflammatory bowel diseases (IBD) are shown to have the same risk in developing COVID-19 infection compared to the normal population: in their medications, the high dose steroid treatment is proved to increase the risk of infection or to make the disease course more serious. The treatment of patients with IBD should be continued without any changes (when the disease is in remission). The use of biologics should be done with special care, with more attention keeping the schedule and the continuity. It is advised to minimise the number of personal visits during the pandemic, they should be substituted with telemedicine. The postponable endoscopic examinations should be temporarily redeemed by non-invasive methods for screening the disease activity and the efficacy of the treatment. The vaccination against COVID-19 is advised in the population with IBD. All vaccines currently available are usable in this patient group (the use of vaccines containing live agents are contraindicated). In the case of patients treated with immunmodulators, steroids or anti-tumor necrosis factor (TNF) alpha, a possible lower efficacy can be expected after the vaccination. 
Keywords: COVID-19, IBD, gastrointestinal, inflammatory bowel disease, coronavirus

Tóbi L, Prehoda B, Balogh A, Dezsőfi-Gottl A, Cseh Á. [The gastrointestinal effects of COVID-19 infection during childhood and among the children affected with inflammatory bowel disease.] Orv Hetil. 2022; 163(6): 214-221.

(Beérkezett: 2021. november 16.; elfogadva: 2021. december 10.)

\begin{abstract}
Rövidítések
anti-TNF (anti-tumor necrosis factor) anti-tumor nekrózis faktor; ASA = (acetylsalicylic acid $)$ acetilszalicilsav; $\mathrm{ACE}=($ angiotensin-converting enzyme) angiotenzinkonvertáló enzim; ARDS = akut respirációs distressz szindróma; COVID-19 = (coronavirus disease 2019) koronavírus-betegség 2019; CRP = C-reaktív protein; ECMO = extracorporalis membránoxigenizáció; $\mathrm{EEN}=($ exclusive enteral nutrition $)$ exkluzív enteralis táplálás; ESPGHAN = (European Society of Paediatric Gastroenterology and Nutrition) Európai Gyermekgasztroenterológiai és Táplálkozástudományi Társaság; GOT = glutamát-oxálacetát-transzamináz; GPT = glutamát-piruvát-transzamináz; IBD = (inflammatory bowel disease) gyulladásos bélbetegség; IOIBD $=($ International Organisation for the Study of Inflammatory Bowel Disease) Nemzetközi Gyulladásos Bélbetegségek Társaság; IQR = (interquartile range) interkvartilis tartomány; $\mathrm{MIS}-\mathrm{C}=$ (multisystem inflammatory syndrome in children) sokszervi gyulladásos szindróma gyermekekben; MRI $=$ (magnetic resonance imaging) mágnesesrezonanciaképalkotás; $\mathrm{OR}=($ odds ratio $)$ esélyhányados; $\mathrm{PCR}=($ polymerase chain reaction) polimeráz-láncreakció; $\mathrm{PCT}=$ (procalcitonin) prokalcitonin; RAAS $=$ (renin-angiotensin-aldosteron system) renin-angiotenzin-aldoszteron rendszer; RNS = ribonukleinsav; SARS-CoV-2 $=$ (severe acute respiratory syndrome coronavirus 2) súlyos akut légúti tünetegyüttest okozó koronavírus-2; SECURE-IBD = Surveillance Epidemiology of Coronavirus Under Research Exclusion -IBD; S-protein = (surface spike glycoprotein) felszíni tüske-glikoprotein; TMPRSS2 = (transmembrane protease serine 2) 2-es típusú transzmembrán szerin-proteáz; TNF = tumornekrózis-faktor
\end{abstract}

A SARS-CoV-2 egy új típusú koronavírus, mely először 2019 decemberében került leírásra Kínában több, kapcsoltan jelentkező, ismeretlen etiológiájú, súlyos tüdőgyulladással diagnosztizált beteg vizsgálatát követően. A vírus okozta fertőzés lehet tünetmentes, vagy okozhatja a COVID-19-et, mely klinikai tüneteiben nagy változatosságot mutat, érintheti bármelyik szervrendszert. A vírus magas transzmissziós kapacitása (minden fertőzött 1,5-6,68 másik embert fertőz meg) és gyors terjedése miatt a WHO 2020. március 11 -én pandémiának minősítette [1-3].

A jelen adatok szerint világszerte 264 millió igazolt és jelentett COVID-19-fertőzöttről tudni, akik közül több mint 5,2 millióan haltak meg. Magyarországon összesen több mint 1125000 fertőzöttet tartanak számon, akik közül 2021. december elejéig közel 35000 beteg hunyt el.

A diagnosztizált betegek körülbelül 1-2\%-a tartozik a gyermekpopulációba, náluk a betegség általában enyhébb lefolyást mutat, mint a megfertőződött felnőttek esetében [4]. Egy 2020-ban publikált metaanalízis adatai alapján a gyermekek körében a COVID-19-fertőzés súlyos lefolyást az esetek 2-5\%-ában mutat, és mindössze a betegek 0,6\%-ának állapota lesz kritikus a fertőzés folyamán. [5]. Amerikai kutatások alapján a fertőzött gyermekek 2,5-4,1\%-a igényel kórházi kezelést. Ennek előfordulása a leggyakoribb a 2 év alatti korosztályban, bár a hospitalizációs ráta kumulatív incidenciája folyamatosan növekszik [6]. A COVID-19-fertőzés mortalitása gyermekkorban az eddigi publikációk alapján $0,1-0,7 \%$ [4].

\section{Patogenezis}

A SARS-CoV-2-fertőzés kialakulásának patomechanizmusában kulcsszerepe van a vírus felszínén található S-proteinnek: ez a szervezetben lévő ACE2-receptorhoz kötődik, mely az emberi szervezetben a legnagyobb számban a légutakban található I-es és II-es típusú pneumocytákon expresszálódik. Az ACE2 az angiotenzinkonvertáló enzim egyik homológja, amely a renin-angiotenzin-aldoszteron rendszer (RAAS) egyik központi enzimje, így fontos szerepet játszik a szervezet múködésének szabályozásában. A receptorhoz való kötődést követően a megfertőződéshez hozzájárul egy 2-es típusú transzmembrán szerin-proteáz (TMPRSS2), melynek a sejt és a vírus membránjának fúziójában van szerepe. Az emberi szervezetben az ACE2 és a TMPRSS2 a legnagyobb mértékben a tüdőben expresszálódik (fóleg az epithelsejtek által), ami magyarázatot ad arra, hogy miért a tüdő a legfogékonyabb a SARS-CoV-2-fertőzésre.

A tüdőn kívül ACE2-receptor még sok extrapulmonalis szövetben is megtalálható: többek között az emésztőrendszerben, a szívben, a májban és a vesékben. A receptor nagy mennyiségben megtalálható a vékonybél differenciálódott epithelsejtjeinek luminaris felszínén a colonban és a cryptasejteken ennél alacsonyabb a szintje. Valószínúsíthető, hogy a SARS-CoV-2 replikálódik a gastrointestinalis tractusban, az intestinalis enterocyták segítségével. Az ACE2-receptornak több szerepe is ismert a gastrointestinalis rendszerben: szükséges az aminosavak felszívódásához és a bélhomeostasis fenntartásához is [7].

A tüdő-bél tengelynek szintén fontos szerepe van a COVID-19-fertőzés patogenezisében, a gastrointestinalis tünetek kialakulásában. A hiperaktív immunrendszer által túltermelt gyulladásos mediátorok citokinvihart idéznek elő, ami a tüdő hiperpermeabilitását okozza: így 
a vírus és a gyulladásos mediátorok a keringéssel a belekbe jutnak, és az enterocyták ACE2-receptoraihoz kötődnek. Az immunreakció dysbiosist okoz a belekben, ami önmagában is hozzájárul a proinflammatorikus állapot kialakulásához. A bakteriális transzlokáció a fertőzés egyik korai lépése, amelyet a belek immunreakció miatti károsodása és a SARS-CoV-2-fertőzés miatti bélbarrierkárosodás idéz elő: a helyi gyulladás és a vírusreplikáció tovább gyengíti a nyálkahártya-barriert, ami hozzájárul a további epitheliumkárosodás kialakulásához - ez lehet az egyik oka a COVID-19-fertőzés kapcsán fellépő gastrointestinalis tünetek kialakulásának. Ezenfelül az emésztőrendszeri tünetek megjelenéséhez szintén hozzájárulhat az ACE2 enzim diszfunkciós múködése - a RAAS kulcsenzimeként a bélimmunfunkciók és -gyulladás modulálásában van nagy szerepe: az ACE2 funkciójának zavara esetén az intestinalis homeostasis zavart szenved, fogékonyabbá téve az emésztőrendszert a fertőzésekre és a gyulladásos folyamatokra. 30 igazolt COVID-19-beteg székletmintáinak génszekvenálással történő elemzését követôen arra az eredményre jutottak, hogy a fertőzés kapcsán a bakteriális diverzitás csökkenése volt megfigyelhető minden betegnél, főként a jótékony baktériumok számának csökkenése volt jellemző [7].

\section{Transzmisszió}

A gyermekek általában a légutakon vagy a conjunctiván keresztül, aeroszolok formájában fertőződnek meg a vírussal. A fertőződésben nagy szerepe van a korábban légúti váladékkal szennyezett kéz szájhoz, szemekhez, orrhoz való érintésének. Ezeken felül a vírus a korábban aeroszollal szennyezett felületek révén is fertőzhet [2].

Több kutatás is vizsgálta a faecooralis fertőződés lehetőségét. Igazolt betegek székletmintáinak vizsgálatakor azt találták, hogy a mintákban kimutatható a SARSCoV-2-RNS, továbbá izolálhatók infektív virionok is,

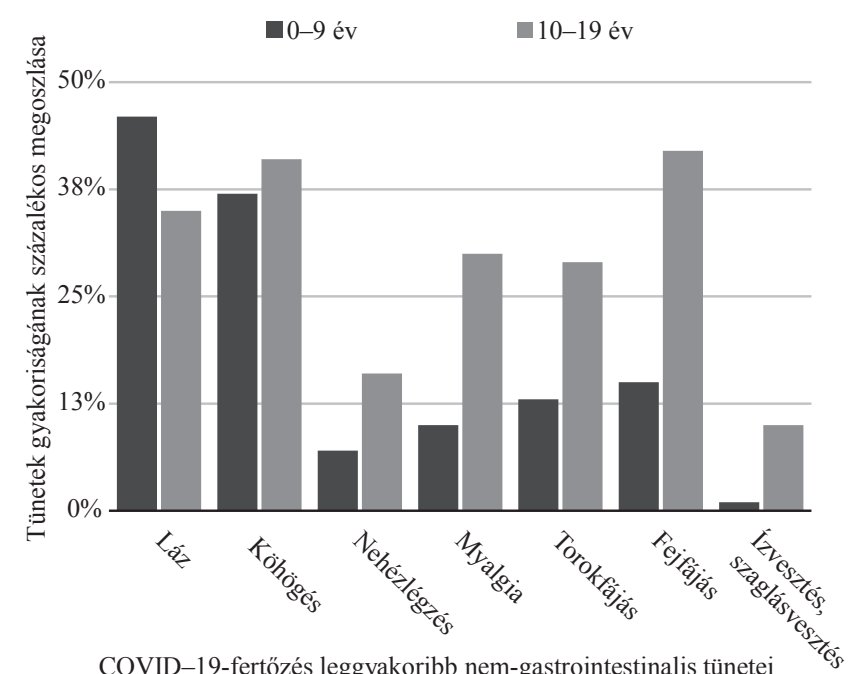

1. ábra $\quad$ A leggyakoribb nem gastrointestinalis tünetek korosztályok szerinti megoszlása gyermekkorban [6] melyek arra utalhatnak, hogy a vírus aktívan megfertózni, majd szaporodni képes a gastrointestinalis tractusban $[7,8]$. A vizsgált betegpopulációkban a SARS-CoV-2RNS 2-5 nappal a légúti minták pozitivitása után lett pozitív, majd ez 1-12 napig tartott még azután is, hogy a vírus már nem volt kimutatható a légúti mintákból. Érdekes kutatási eredmény, hogy a gyermekek általában hosszabb időn keresztül ürítik a székletükkel a vírust (akár 5 héten keresztül), mint a felnőtt betegek $[2,7,9]$. Egy Kínában végzett kutatásban azt találták, hogy 10ből 8 gyermek rectalis mintái mutatnak PCR-pozitivitást, miután a nasopharyngealis minták már negatív eredményt adtak [10]. Ezen kutatási eredmények megerősítették a korábbi felvetéseket, melyek szerint a fertőződés átadható faecooralisan is.

\section{Tünettan, betegséglefolyás}

A diagnosztizált gyermekek átlagéletkora 7,6 év ( $\mathrm{n}=$ $7480)$, melyben enyhe férfidominancia figyelhetó meg $(1,15-1,55 \times) .1,2$ millió igazolt gyermekkori COVID19-fertőzést elemezve a betegség megjelenésének gyakorisága még a gyermekkori populáción belül is különbségeket mutat: $17,4 \%$ volt 4 év alatti gyermek, $18,6 \%$ $11-13$ éves, $25,7 \%$ 5-10 éves és 38,3\% 14-17 éves [11]. Vizsgálatok alapján a megfertőződéstől a tünetek kialakulásáig átlagosan eltelt idő 9 nap, a tünetek megszúnéséig pedig 16 nap $[6,12]$.

A megfertőződött gyermekek körében vizsgált faktorok közül eddig a csecsemókort, a krónikus betegségeket (asztma vagy egyéb légúti betegség, diabetes), az obesitast, a veleszületett kórállapotokat (genetikai, neurológiai, metabolikus betegségek, congenitalis szívbetegségek) és a súlyos immunszuppressziót írták le mint igazolt rizikótényezőket COVID-19-betegség kialakulására vagy súlyosabb betegséglefolyásra. Multicentrikus vizsgálatok alapján a COVID-19-fertőzésben elhunyt gyermekek 75\%-ának volt legalább egy alapbetegsége [6].

Egy 4857 SARS-CoV-2-fertőzött gyermeket vizsgáló, összefoglaló közlemény alapján a gyermekek 23\%-ánál tünetmentesen zajlik le a fertőzés [13]. Érdekes azonban, hogy a tünetmentes esetek 30\%-ában képalkotó vizsgálattal mégis kimutathatók elváltozások a tüdóben [12].

Egy szisztematikus elemzés alapján (5188 0-9 éves, 12689 10-19 éves beteg) a gyermekek leggyakoribb tünetei a láz, a köhögés, illetve a gastrointestinalis tünetek voltak mindkét korcsoportban. A leggyakoribb nem gastrointestinalis tünetek korosztályok szerinti megoszlását az 1. ábra mutatja be [6].

Több, COVID-19-fertőzött gyermek bevonásával készült kutatás $(\mathrm{n}=3028-17877)$ adatai alapján gastrointestinalis tünetek a betegek 18-32\%-ánál jelentek meg. Ezek közül a leggyakoribbak a hasmenés (15\%), a hányinger és hányás (10\%), a hasi fájdalom $(6-8 \%)$ voltak (2. ábra) $[2,6,12]$. Gyakran jelentkezik még étvágytalanság, táplálási nehezítettség is a fertőzéshez kapcsolódóan. 


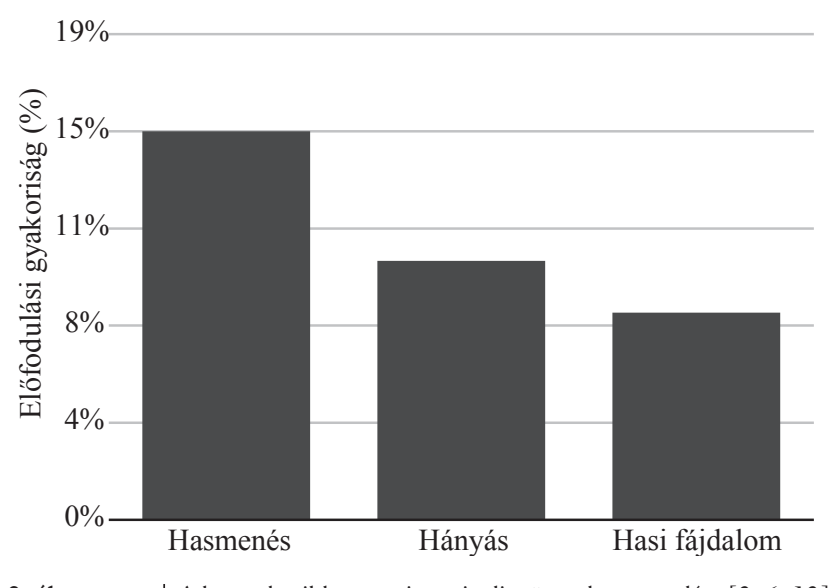

2. ábra |A leggyakoribb gastrointestinalis tünetek megoszlása [2, 6, 12]

A hányás inkább a gyermekpopulációban jellemző, míg a hasmenés a leggyakoribb gastrointestinalis tünet mind gyermekkori, mind felnőttkori COVID-19-infekcióban. A gyermekkori esetek 22\%-ában a vizes hasmenés az első tünete a betegségnek: a fertőződést követően általában 1-8 nappal késóbb jelenik meg, mediánja 3,3 nap [10]. A COVID-19-fertőzés által okozott gastrointestinalis tünetek nem specifikusak, lázzal társulva sok gyermekkori betegség (virális enteritis, gyulladásos bélbetegség, appendicitis) tüneteire hasonlíthatnak, így valódi gyakoriságuk a jelentett és így a publikációkban összegzett számoknál valószínúleg magasabb $[2,6,12]$.

$\mathrm{Az}$ Olasz Nemzeti Egészségügyi Intézet által végzett, 127 SARS-CoV-2-fertőzött gyermek adatait összegző kutatás azt találta, hogy a gastrointestinalis tünetek megoszlása a betegek körében nem egyforma a különbözó súlyosságú betegséglefolyást mutató csoportok között $(\mathrm{p}=0,006)$ : megjelenésük gyakrabban társult súlyos vagy kritikus betegséglefolyással $(\mathrm{p}=0,029)$. Ezenfelül az emésztőrendszeri tünetek jelenléte pozitív korrelációt mutatott a cardialis szövődmények megjelenésével is $(\mathrm{p}=0,007)[14]$.

\section{Laboratóriumi eredmények}

Egy 4857 SARS-CoV-2-fertőzött gyermeket vizsgáló kutatás, illetve több, kisebb betegszámú vizsgálat adatai alapján a gyermekek körében a leggyakrabban normális fehérvérsejtszám figyelhetô meg a betegség kapcsán (60-83\%). Amennyiben eltérés adódik, úgy legtöbbször leukopenia jelentkezik, ez a betegek 16\%-ában látható (ezzel szemben a betegek 12\%-ánál éppen leukocytosis figyelhető meg).

Felnőtt betegek vizsgálatakor a magas neutrophilszám korrelációt mutatott a betegség súlyosságával: a COVID-19-fertőzés kapcsán elhunyt vagy kifejezetten súlyos kórlefolyást mutató betegek szervezetében magasabb neutrophilsejtszám volt megfigyelhető, mint a fertőzést átvészelők szervezetében [8]. Gyermekek körében a neutrophilia közel ugyanolyan gyakorisággal fordul elö, mint a neutropenia $(4,6 \%$ vs. $3-6 \%)[3,15]$.
A vizsgált gyermekek 3-12\%-ánál lymphocytopenia figyelhető meg. Érdekes kutatási eredmény, hogy egy vizsgálat folyamán felnőttek esetében lymphocytopenia a súlyos betegséglefolyást mutató esetek $83,2 \%$-ában volt kimutatható a kórházi felvételt követően [8].

A SARS-CoV-2-fertőzött gyermekek nagy részénél emelkedett gyulladásos értékek láthatók: 25\%-nál emelkedett PCT-érték, 16\%-nál magas CRP és 9\%-nál gyorsult süllyedés figyelhetô meg.

551 COVID-19-beteg vizsgálata alapján a gyermekek 9\%-ánál GPT- és 18\%-ánál GOT-emelkedés volt megfigyelhető; ezzel szemben csak a betegek 1,9\%-ánál találtak akut májkárosodást [16]. A transzaminázok emelkedése gyakrabban figyelhetô meg a súlyos kórlefolyást mutató esetekben, mint az enyhébbekben $(40-60 \%$ vs. $18-25 \%$ ) [10].

\section{Sokszervi gyulladásos szindróma gyermekekben}

A MIS-C prevalenciája a COVID-19 megjelenése óta folyamatosan növekszik. Először 2020 áprilisában írták le Londonban mint a COVID-fertőzéshez köthető, Kawasaki-szerú betegséget: az általuk dokumentált 8 esetből 1 gyermek meghalt. Ez egy viszonylag ritka (az igazolt COVID-19-fertőzött gyermekek kevesebb mint 1\%-a érintett), de a COVID-19-fertőzéshez képest nagyobb mortalitással és morbiditással járó, COVID19-infekció után megjelenő sokszervi kórkép, melyre a variábilis klinikai prezentáción belül dominánsan jellemzô a láz és a gastrointestinalis tünetek együttes megjelenése. Kialakulásának pontos mechanizmusa nem tisztázott, jelenleg immunmediált posztinfekciózus kórképnek tartják $[17,18]$. A MIS-C a megjelenésében nagyban hasonlít a Kawasaki-kórhoz, de tünetei hasonlítanak a makrofágaktivációs szindróma és a toxikus sokk szindróma tüneteihez is.

Egy 655 beteg bevonásával végzett vizsgálatban a MIS-C-vel diagnosztizált gyermekek kora 1 év és 20 év közé esett, a medián 8-11 év volt. A vizsgált gyermekek $55 \%$-a volt fiú (1,2: 1 arány).

A diagnosztizált gyermekek 23,3\%-ának volt valamilyen komorbid betegsége: legtöbbjük túlsúlyos volt (13,28\%), míg 5,95\%-uknak volt légúti betegsége [17].

Utánkövetéses vizsgálatok alapján a COVID-19-fertőzés tüneteinek és a MIS-C tüneteinek megjelenése közötti átlagos időtartam 25 nap [4]. A MIS-C tüneteinek kezdete és a kórházi felvétel között eltelt átlagos idő (655 MIC-S-beteg vizsgálata alapján) 4 nap (IQR = 3-6 nap) [17].

A szindróma leggyakoribb tünete a láz (80-100\%), melyet a gastrointestinalis tünetek (hasi fájdalom, hasmenés, hányás) követnek (60-100\%). A láz általában 3-5 napon keresztül tart, bár egy kisebb, 186 betegen végzett kutatás alapján a betegek $78 \%$-ának 5 napon túl is láza volt. A gastrointestinalis tünetek nem specifikusak, gyakran olyan súlyosak, hogy akut sebészeti kórkép gyanúját vetik fel. 
A korábban említett tüneteken kívül gyakori még a cardialis érintettség (74\%), a hypotensio (28\%), a sokk (32-76\%), a bőrtünetek (45-76\%), a nyálkahártyák érintettsége (cheilitis, epernyelv) (27-76\%), a conjunctivitis (30-81\%) és a légzőrendszeri tünetek (köhögés, nehézlégzés, összesen 21-65\%), a neurokognitív tünetek (fejfájás, letargia, zavartság, összesen 29-58\%), a myalgia (8-17\%), a láb- és kézfejödéma (9-16\%), a lymphadenopathia $(6-16 \%)$ [17].

Több retrospektív vizsgálat eredményei alapján (302655 vizsgált gyermek) a MIS-C-vel diagnosztizált gyermekek 100\%-a kórházi felvételt igényelt, míg 68\%-uk szorult intenzív osztályos ellátásra. A kórházban töltött idő 4-13 nap között volt átlagosan, medián 7 nap volt. Az ebben a kutatásban vizsgált gyermekek közül 37\%nak volt szüksége noninvazív, míg 32\%-nak invazív lélegeztetésre, 3-5\% extracorporalis membránoxigenizációt (ECMO-t) igényelt. Gyógyszeres kezelésükben 41\%-nak volt szüksége keringéstámogatásra, $81 \%$-uk részesült antikoagulálásban, 70\%-uk intravénás immunglobulint és 49\%-uk szteroidot kapott. A vizsgált gyermekek 1,331,7\%-a halálozott el [4, 17, 19].

\section{A COVID-19 és a gyermekkori gyulladásos bélbetegség}

A pandémia során kiemelt figyelmet kapnak a krónikus betegek, közülük is kiemelendők a gyulladásos bélbetegek, mert az emésztőrendszer érintettsége, illetve a kezelésükben használt immunszuppresszív szerek miatt potenciálisan nagyobb veszélynek lehetnek kitéve a fertőzés szempontjából, mint az átlagpopuláció [1].

\section{Patomechanizmus a gyulladásos bélbeteg gyermekekben}

COVID-19 esetén az ACE2-receptor kiemelkedően nagy mennyiségben expresszálódik az intestinalis epithelsejteken, fóleg a terminalis ileumban. Vizsgálatok alapján az aktív gyulladást mutató szövettani minták magasabb ACE2-receptor-expressziót mutatnak a terminalis ileumban és a colonban is a kontrollmintákhoz képest. Az éppen remisszióban lévő, de gyulladásos bélbetegséggel diagnosztizált betegek colonjában nyugalomban is magasabb ACE2-receptor-expresszió mérhető, mint az átlagpopulációnál. Ezenfelül az IBD-ben expresszált proinflammatorikus citokinek tovább növelhetik az ACE2-receptorok expresszióját [20]. A COVID-19-fertőzés kialakulásához elengedhetetlen, az S-protein aktivációjában részt vevő tripszinszerú proteázok aktivitása fokozott a gyulladásos bélbetegségek esetén, mely így potenciálisan megkönnyítheti a fertőzés kialakulását [8] [7].

Összességében ezek a faktorok arra utalhatnak, hogy a gyulladásos bélbeteg populáció fogékonyabb lehet a COVID-19-fertőzés kialakulására, mint a kontrollpopu- láció: ezzel szemben a gyakorlatban, illetve a publikált kutatások alapján jelenleg azt látni, hogy a gyulladásos bélbetegek nem fogékonyabbak a SARS-CoV-2-fertőzésre, mint az átlagpopuláció, sőt néhány kutatás eredményei alapján körükben még alacsonyabb a fertőzöttek aránya [12]. Ennek egyik oka lehet, hogy az IBD-s betegek szervezetében a szabad ACE2 szintje a vizsgálatok alapján magasabb, mint a kontrollpopulációban: ez kompetitív faktorként gátolhatja az S-protein kötődését, csökkentve ezzel a fogékonyságot a betegség kialakulására [8]. Egy 1918 felnőtt beteg bevonásával készült vizsgálatban a SARS-CoV-2-fertőzést elkapó gyulladásos bélbetegek kumulatív incidenciája 6,1 volt 1000 betegre vonatkoztatva, mely alacsonyabb az átlagpopulációnál (OR 0,74, p<0,001).

\section{A COVID-19-fertözés lefolyása a gyulladásos bélbeteg gyermekekben}

A megfertőződött gyulladásos bélbeteg gyermekek kórlefolyása a kontroll-gyermekpopulációéhoz hasonló COVID-19-fertőzés esetén: egy 209 IBD-s gyermeket vizsgáló kutatásban (SECURE-IBD) azt találták, hogy mindössze a betegek 7\%-a $(\mathrm{n}=14)$ igényelt kórházi kezelést, akik közül összesen 2 gyermeket (1\%) kellett lélegeztetni. Egy beteg sem halálozott el a fertőzés következtében [20].

A Portói Munkacsoport kutatásába bevont 102 klinikán összesen 7, IBD-vel kezelt gyermek esett át igazoltan COVID-19-fertőzésen 2020 márciusáig. Mindegyik gyermeknél enyhe lefolyást mutatott a fertőzés, kórházi felvételre nem szorultak. A gyermekek közül volt, aki immunszuppresszív terápiában, volt, aki szteroidkezelésben, és volt, aki biológiai terápiában részesült a fertőzés idején; egyikük sem igényelt terápiamódosítást. A gyulladásos bélbetegség mindegyik gyermeknél remisszióban maradt a COVID-19-fertőzés idején [21].

A jelenlegi publikációk szerint jelenleg még nincs adat arra vonatkozóan, hogy a COVID-19-fertőzés önmagában okozhat-e relapsust, vagy következtében kialakulhat-e de novo IBD [22].

\section{Az ellátási rendszer változásai a pandémia idején}

Az ESPGHAN (European Society of Paediatric Gastroenterology and Nutrition) Portói Munkacsoportja 32 európai IBD-centrum beteggondozási rutinjainak változását vizsgálta a COVID-19-pandémia idején. A centrumok 97\%-a váltotta át a személyes vizitek egy részét online vizitekre, emellett 30 centrum (94\%) a lehetséges minimumra csökkentette a klinikákon a személyes megjelenések számát (csak relapsus, infúziós terápia vagy gyógyszerkiváltás kapcsán hívták be a betegeket). 31 centrumban $(97 \%)$ nem javasolták a korábban beállított terápia módosítását a COVID-19-pandémia miatt [21]. 
Tekintettel arra, hogy a gyulladásos bélbetegek a jelenlegi adatok alapján nincsenek kitéve nagyobb veszélynek a COVID-19-fertőzéssel szemben, mint az átlagpopuláció, rendszeres, szűrő jellegű SARS-CoV-2-PCRvizsgálatuk nem indokolt. Amennyiben COVID-19-fertőzésre jellemző tüneteik vannak, kontaktusba kerültek igazoltan fertőzött személlyel, relapsusuk zajlik, illetve kórházi felvételük, invazív vizsgálatuk tervezett, akkor a jelenlegi ajánlások szerint javasolt náluk a SARS-CoV-2PCR-teszt elvégzése [22].

A gyulladásos bélbetegségek diagnosztikájában és utánkövetésében is nagy szerepük van az endoszkópos vizsgálatoknak. A pandémia idején remisszióban lévő betegeknél, a biomarkerek változása által nem alátámasztott enyhe vagy középsúlyos relapsus esetén és a régóta fennálló IBD-s betegek esetén a rutin szürő jellegű endoszkópos vizsgálat elhalasztása javasolt. A magas prioritású endoszkópos vizsgálatok előtt (akut gastrointestinalis vérzés, de novo IBD, cholangitis IBD-ben, részleges bélelzáródás) a betegek SARS-CoV-2-PCR-vizsgálata javasolt. Az elhalasztott endoszkópos vizsgálatok helyett a pandémia idején a noninvazív vizsgálómódszerek alkalmazása javasolt a betegség aktivitásának követésére: MRI, enterográfia, kapszulaendoszkópia, hasi ultrahangvizsgálat, székletkalprotektin- és/vagy székletvérvizsgálat. Ezen vizsgálatok szükség esetén kiegészíthetők invazív laborvizsgálatokkal, melyekkel szintén a betegség aktivitását követhetjük nyomon, esetleg szükség szerint gyógyszerszintmérésekkel [22, 23].

\section{A gyulladásos bélbeteg gyermekek gyógyszeres terápiája a pandémia idején}

Az IBD kezelésében használt számos gyógyszerról bebizonyosodott korábban, hogy az intracelluláris jelátviteli útvonalak módosításával vagy gátlásával csökkentik a gazdaszervezet védekezőképességét a fertőzések ellen: ilyenek többek között a kortikoszteroidok - ellentmondásosan ezeket a COVID-19 hatására kialakult ARDSben és hiperinflammatorikus állapotokban a mortalitás csökkentésére használják. Bár képesek a gyulladást csökkenteni, a vírusok elleni választ és így a patogének ürülését is csökkentik, így használatuk az akut fertőzésben a jelenlegi publikációk alapján megosztó [8].

Egy felnőtt gyulladásos bélbetegek körében végzett kutatásban azt találták, hogy minden olyan beteg esetében, aki éppen nagy dózisú szteroidkezelés alatt állt (n = 9), a COVID-19-fertőzés elkapásakor súlyosabb lefolyást mutatott a betegség (ARDS, sokk, veseelégtelenség, másodlagos bakteriális fertőzések alakultak ki), mint azoknál, akik éppen nem álltak szteroidkezelés alatt $(\mathrm{n}=32)[8]$.

Egy 525 gyulladásos bélbeteg bevonásával végzett kutatás eredménye alapján a gyulladásos bélbeteg populációban a szteroidhasználat a legfontosabb rizikófaktor a súlyos COVID-19-fertőzés kialakulásában [20].
A jelenlegi ajánlások alapján a gyulladásos bélbetegek fenntartó terápiáját nem érdemes módosítani, megszakítani a pandémia miatt vagy COVID-19-fertőzés esetén, sőt a gyermekpopulációban a relapsus miatti egészségromlás rizikója jelenleg magasan felülmúlja a COVID19-fertőzés miatt kialakulóét. A pandémia alatt zajló relapsus kezelésére jelenleg nincs általánosan elfogadott irányelv: minden esetben egyéni mérlegelés szükséges az esetleges gyógyszerváltás vagy szteroidbeállítás előtt.

A korábban beállított meszalazin-, szulfaszalazinkészítmények tovább szedhetők: a jelenlegi publikációk eredménye megosztó, néhány esetben nagyobb fertőzésveszélyrôl számoltak be, míg a legtöbb publikációban nem találtak ilyen összefüggést [7].

A biológiai terápiás szerek (adalimumab, infliximab, vedolizumab, ustekinumab) használata folytatandó, nem jelentenek rizikót a COVID-19-fertőzés vagy a súlyosabb betegséglefolyás szempontjából [8]. Ezt alátámasztja több kutatás eredménye is: egy 2021 márciusában publikált vizsgálat szerint a COVID-19-járvány első hulláma alatt a biológiai terápiát később kapó vagy átmenetileg szüneteltető betegek 21-23\%-ában a betegség fellángolása volt megfigyelhető [20]. Ezenfelül a Portói Munkacsoport publikált kutatási eredményeket a biológiai terápia késleltetésének, megszakításának hatásairól. Ök is a korábban említett vizsgálathoz hasonló eredményeket találtak. Kínában 1431 gyulladásos bélbeteg gyermeknél a 2020. január és március között végzett vizsgálatuk adatai alapján az infliximabterápiában részesülő 233 gyermek közül 66 beteg esetében (a biológiai terápiában részesülő gyermekek 28\%-a) késett a kezelés (átlagosan 19,2 \pm 11,5 napot). 2 gyermek esetében (az infliximabterápiában részesülő gyermekek 0,9\%-a) teljesen megszakadt a biológiai terápia adása. Ezen betegek közül 14-ben (az összes beteg gyermek 0,97\%-a, az elhalasztott infliximabterápiában részesült betegek 21\%-a) következett be relapsus. Közülük 10-en igényeltek kórházi felvételt és kezelést, átlagosan 10,4 \pm 6,0 napig (az elhalasztott infliximabterápiában részesült betegek 15\%-a). Összehasonlításként ebben az időben egyéb okból összesen 17 gyermeknek (az összes IBD-s beteg 1,2\%-a) volt relapsusa ( 10 betegnél compliance-probléma, 5 betegnél terápiarezisztens alapbetegség és 2 gyermeknél Clostridium difficile fertőzés miatt) [21].

$\mathrm{Az}$ anti-TNF-kezelés (adalimumab, infliximab) gyakran alkalmazott terápia gyulladásos bélbetegek fenntartó terápiájaként. A TNF-szint vizsgálata különböző eredményeket mutat COVID-19-fertőzés esetén: néhány esetben nem volt szignifikáns különbség a vizsgált, különböző kórlefolyású betegcsoportok között, míg újabb publikációk alapján az intenzív osztályos ellátást igénylő betegek esetén szignifikánsan magasabb TNF-alfa-szint volt kimutatható. A TNF több módon is befolyásolhatja a COVID-19-fertőzés alakulását: növelheti az ACE2-receptor-szintet, vagy fokozhatja a lymphopeniát a direkt leukocytaapoptosis kiváltásával. Ezen felvetések szerint a TNF-szint csökkentése, ezáltal az anti-TNF-terápia 
potenciálisan védő hatású lehet a súlyosabb COVID-19lefolyással szemben. A SECURE-IBD-regiszter, melyben 209 COVID-19-fertőzött IBD-s gyermek kórlefolyását vizsgálták, szintén erre a következtetésre jutott: a TNF-antagonista monoterápiával kezelt gyermekek körében kisebb arányban volt szükséges hospitalizáció a fertőzés esetén $[8,7]$.

Az intravénás infliximab forszírozott cseréje sem javasolt a subcutan adagolható adalimumabra, csak a COVID-19-fertőzés miatt. Egy 73 beteggel végzett vizsgálat alapján az infliximab mellett remisszióban lévő betegek gyógyszerének adalimumabra történő váltása a betegek 47\%-ánál 1 éven belül hatékonyságcsökkenést, toleranciakialakulást okozott [24].

Egy 244 IBD-s gyermeket vizsgáló kutatás eredményei alapján a betegek 54,9\%-a érezte úgy, hogy nem kapott megfelelő tájékoztatást a COVID-19 potenciális hatásairól a betegségére és gyógyszereire. A SARS-CoV2 -fertőzéstől való félelmük miatt a betegek 34,4\%-a nem jár kontrollvizsgálatokra a pandémia idején. A gyermekek 9\%-a gondolkozik a gyógyszerei változtatásán, míg 2,9\%-uk már változtatott, vagy teljesen abbahagyta a szedésüket a vírusveszély miatt. A kezelést elhagyók közül $0,8 \%$ az anti-TNF-terápiát, $0,8 \%$ az 5-ASA-t, $0,8 \%$ az antibiotikumot és $0,4 \%$ az EEN-t hagyta el [25].

Amennyiben a pandémia alatt a gyulladásos bélbetegség relapsusa következik be, a betegeket javasolt tesztelni SARS-CoV-2-fertőzésre, bár a jelenlegi kutatások nem igazolták még, hogy önmagában a COVID-19-fertőzés IBD-relapsust válthat ki. Amennyiben szükséges, a terápia változtatása, a pandémia elött alkalmazott irányelvek szerint javasolt új gyógyszerek bevezetésének rendje is megegyezik a pandémia előtti ajánlásokkal [23, 26].

Összefoglalásként kijelenthető, hogy önmagában a gyulladásos bélbetegség nem rizikófaktora a COVID19-fertőzés kialakulásának vagy a súlyosabb betegségle-

1. táblázat $\mid$ Az IOIBD javaslatai a gyulladásos bélbetegek vakcinációjával kapcsolatban COVID-19 ellen [27]

1. A gyulladásos bélbetegek vakcinációja javasolt COVID-19 ellen.

2. A vakcinációt a legkorábbi lehetséges idôpontban javasolt elvégezni; ezt a betegség aktivitása sem befolyásolja.

3. SARS-CoV-2 elleni vakcinációra az mRNS-vakcinák, replikációra képtelen vektorvakcinák, inaktivált vakcinák és rekombináns vakcinák is alkalmasak a gyulladásos bélbetegek körében.

4. A vakcinációt nem javasolt elhalasztani azért, mert a beteg immunszuppresszív kezelésben részesül.

5. A gyulladásos bélbetegek képesek lehetnek a megfeleló immunválasz kialakítására a vakcináció során, azonban minden immunmoduláns, kortikoszteroid- és anti-TNF-terápia esetén számolni

6. A biológiai terápiában részesülő betegek a ciklus közben bármikor olthatóak.

7. A COVID-19 elleni vakcináció nem valószínú, hogy relapsust váltson ki.

anti-TNF = anti-tumornekrózis-faktor; COVID-19 = koronavírus-betegség 2019; IOIBD = Nemzetközi Gyulladásos Bélbetegségek Társaság; $\mathrm{mRNS}$ = hírvivő ribonukleinsav; SARS-CoV-2 = súlyos akut légúti tünetegyüttest okozó koronavírus-2 folyásnak gyermekkorban. Jelenlegi ismereteink szerint a kezelésében használt gyógyszerek közül csak a nagy adagú kortikoszteroid növeli ennek kockázatát.

\section{A gyulladásos bélbetegek vakcinációja COVID-19 ellen}

2021 januárjában publikálta az IOIBD (International Organisation for the Study of Inflammatory Bowel Disease) kutatócsoportja az eddig megjelent egyetlen hivatalos irányelvet a gyulladásos bélbetegek oltásával kapcsolatban. Az elfogadott javaslatok közül kiemeltek az 1. táblázatban olvashatók [27].

\section{A pandémia pszichés hatásai a krónikus betegek körében}

A pandémia miatti változások egyik alulbecsült hatását a betegek pszichés változásai adják. A pszichológiai problémák, szorongás, depresszió megjelenése gyakoribb azok körében, akik krónikus betegséggel élnek. Mivel a pandémia alatt a személyes orvos-beteg találkozások száma nagymértékben csökkent, a napi rutin megváltozása, a szociális tevékenységek hiánya, a korábban ismeretlen távoktatás, az aggódás a családjuk és a jövő miatt nagyban ronthat a betegek tünetein, így még kiemelkedőbb szerepe van ebben az időszakban a gondozott betegek számára a pszichés támogatás biztosításának [7].

A biopszichoszociális modell alapján, mely jelenleg a legszélesebb körben elfogadott patogenetikai magyarázata a funkcionális gasztroenterológiai betegségeknek, a pszichológiai stressznek kiemelkedő szerepe van a funkcionális betegségek kialakulásában. Egy japán kutatás szerint a gyermek- és tinédzserkorosztály 11,9\%-ában jelentkezett valamilyen gastrointestinalis tünet a lezárások, iskolai változások miatt okozott stressz hatására [20].

\section{Következtetés}

A SARS-CoV-2-infekció változatos kórlefolyást mutató, a gyermekpopulációt egyre növekvő mértékben érintő fertőzés. Körükben az idősebb korosztállyal szemben sokkal gyakoribbak a gastrointestinalis tünetek, a betegek 18-32\%-ánál jelentkezik legalább egy. A COVID-19 emésztőrendszeri tünetei nem specifikusak, gyakran megegyezhetnek a virális enteritis, a gyulladásos bélbetegségek vagy a vakbélgyulladás tüneteivel. A gyermekkori SARS-CoV-2-infekció egy viszonylag ritka, de súlyos szövődménye a MIS-C: ilyenkor a gastrointestinalis tünetek gyakorisága 60-100\%-ra nő, gyakran akut has benyomását keltve.

A gyulladásos bélbeteg gyermekpopuláció az alapbetegsége miatt nincs nagyobb veszélynek kitéve az átlagpopulációhoz képest a COVID-19-fertőzés szempontjából: terápiájukban a nagy dózisú szteroidkezelés okoz növekedett rizikót a megfertőződésre, illetve a súlyosabb 
betegséglefolyásra. Az IBD-s betegek fenntartó terápiájának módosítások nélküli folytatása javasolt (remisszióban lévő betegség esetén), kiemelt figyelmet fordítva a biológiai terápiák időben történő, megszakítás nélküli alkalmazására. Törekedni kell a személyes vizitek számának csökkentésére a pandémia idején, ezek telemedicinával történő helyettesítése javasolt. A halasztható endoszkópos vizsgálatok noninvazív vizsgálómódszerekkel történő átmeneti kiváltása részesítendő előnyben a betegség aktivitásának, a terápia hatékonyságának megítélésére. A gyulladásos bélbeteg populáció COVID-19 elleni védőoltása javasolt, jelenleg minden elérhető oltóanyag alkalmazható náluk (az élő ágenst tartalmazó vakcinák kontraindikáltak). Immunmoduláns, szteroidvagy anti-TNF-alfa-terápia esetén a vakcináció lehetséges csökkent hatékonyságával kell számolni.

Anyagi támogatás: EFOP-3.6.3-VEKOP-16-2017-00009 - Rendszeres PhD-fokozat-szerzési Kiválósági Ösztöndíj.

Szerzői munkamegosztás: T. L.: Az irodalom áttekintése és a közlemény megírása. D.-G. A., Cs. Á., B. A., P. B.: A cikk szakmai korrektúrázása. A cikk végleges változatát valamennyi szerző elolvasta és jóváhagyta.

Érdekeltségek: A szerzőknek nincsenek érdekeltségeik.

\section{Irodalom}

[1] D'Amico F, Danese S, Peyrin-Biroulet L. Systematic review on inflammatory bowel disease patients with coronavirus disease 2019: it is time to take stock. Clin Gastroenterol Hepatol. 2020; 18: 2689-2700.

[2] Oba J, Carvalho WB, Silva CA, et al. Gastrointestinal manifestations and nutritional therapy during COVID-19 pandemic: a practical guide for pediatricians. Einstein (São Paulo) 2020; 18: eRW5774.

[3] Rathore V, Galhotra A, Pal R, et al. COVID-19 Pandemic and children: a review. J Pediatr Pharmacol Ther. 2020; 25: 574 585 .

[4] Rabinowicz S, Leshem E, Pessach IM. COVID-19 in the pediatric population. Review and current evidence. Curr Infect Dis Rep. 2020; $22: 29$.

[5] Pereira MF, Litvinov N, Farhat SC, et al. Severe clinical spectrum with high mortality in pediatric patients with COVID-19 and multisystem inflammatory syndrome. Clinics (São Paulo) 2020; 75: e2209.

[6] Gonzalez Jimenez D, Velasco Rodríguez-Belvís M, Ferrer Gonzalez P, et al. COVID-19 gastrointestinal manifestations are in dependent predictors of PICU admission in hospitalized pediatric patients. Pediatr Infect Dis J. 2020; 39: e459-e462.

[7] Puoti MG, Rybak A, Kiparissi F, et al. SARS-CoV-2 and the gastrointestinal tract in children. Front Pediatr. 2021; 9: 617980.

[8] Neurath MF. COVID-19 and immunomodulation in IBD. Gut 2020; 69: 1335-1342.

[9] Fragoso RP, Rodrigues M. COVID-19 and pediatric inflammatory bowel disease. How to manage it? Clinics (São Paulo) 2020; 75: e1962.

[10] Matthai J, Shanmugam N, Sobhan P, et al. Coronavirus disease (COVID-19) and the gastrointestinal system in children. Indian Pediatr. 2020; S097475591600162.
[11] Deville JG, Song E, Ouellette CP. COVID-19: clinical manifestations and diagnosis in children. Available from: https://www. uptodate.com/contents/covid-19-clinical-manifestations-anddiagnosis-in-children/print [accessed: Nov 25, 2021]

[12] Guo CX, He L, Yin JY, et al. Epidemiological and clinical features of pediatric COVID-19. BMC Med. 2020; 18: 250.

[13] Meena J, Yadav J, Saini L, et al. Clinical features and outcome of SARS-CoV-2 infection in children: a systematic review and metaanalysis. Indian Pediatr. 2020; 57: 820-826.

[14] Giacomet V, Barcellini L, Stracuzzi M, et al. Gastrointestinal symptoms in severe COVID-19 children. Pediatr Infect Dis J. 2020; 39: e317-e320.

[15] Zimmermann P, Curtis N. Coronavirus infections in children including COVID-19: an overview of the epidemiology, clinical features, diagnosis, treatment and prevention options in children. Pediatr Infect Dis J. 2020; 39: 355-368.

[16] Pousa PA, Mendonça TS, Oliveira EA, et al. Extrapulmonary manifestations of COVID-19 in children: a comprehensive review and pathophysiological considerations. J Pediatr. 2021; 97: 116-139.

[17] Kaushik A, Gupta S, Sood M, et al. A systematic review of multisystem inflammatory syndrome in children associated with SARSCoV-2 infection. Pediatr Infect Dis J. 2020; 39: e340-e346.

[18] Beth M, Son F, Friedman K. COVID-19: Multisystem inflammatory syndrome in children (MIS-C) clinical features, evaluation, and diagnosis. Available from: https://www.uptodate.com/ contents / covid-19-multisystem-inflammatory-syndrome-inchildren-mis-c-clinical-features-evaluation-and-diagnosis [accessed: Nov 25, 2021].

[19] Baradaran A, Malek A, Moazzen N, et al. COVID-19 associated multisystem inflammatory syndrome: a systematic review and meta-analysis. Iran J Allergy Asthma Immunol. 2020; 19: 570-588.

[20] Dipasquale V, Passanisi S, Cucinotta U, et al. Implications of SARS-COV-2 infection in the diagnosis and management of the pediatric gastrointestinal disease. Ital J Pediatr. 2021; 47: 71.

[21] Magro F, Rahier JF, Abreu C, et al. Inflammatory bowel disease management during the COVID-19 outbreak: the ten do's and don'ts from the ECCO-COVID taskforce. J Crohns Colitis 2020; 14(Suppl 3): S798-S806

[22] Dorfman L, Nassar R, Binjamin Ohana D, et al. Pediatric inflammatory bowel disease and the effect of COVID-19 pandemic on treatment adherence and patients' behavior. Pediatr Res. 2021; 90: 637-641.

[23] Siegel CA, Melmed GY, McGovern DP, et al. SARS-CoV-2 vaccination for patients with inflammatory bowel diseases: recommendations from an international consensus meeting. Gut 2021; 70: 635-640.

[24] Turner D, Huang Y, Martín-de-Carpi J, et al. Corona virus disease 2019 and paediatric inflammatory bowel diseases: global experience and provisional guidance (March 2020) from the Paediatric IBD Porto Group of European Society of Paediatric Gastroenterology, Hepatology, and Nutrition. J Pediatr Gastroenterol Nutr. 2020; 70: 727-733.

[25] Ng SC, Mak JW, Hitz L, et al. COVID-19 Pandemic: which IBD patients need to be scoped, who gets scoped now, who can wait, and how to resume to normal. J Crohns Colitis 2020; 14(Suppl 3): S791-S797.

[26] Resál T, Rutka M, Szántó K, et al. The treatment of inflammatory bowel disease during the SARS-CoV-2 epidemic - practical advices. [A gyulladásos bélbetegségek kezelése a SARS-CoV-2járvány idején - gyakorlati javaslatok.] Orv Hetil. 2020; 161: 1022-1027. [Hungarian]

[27] Arrigo S, Alvisi P, Banzato C, et al. Management of paediatric IBD after the peak of COVID-19 pandemic in Italy: a position paper on behalf of the SIGENP IBD working group. Dig Liver Dis. 2021 ; 53 : 183-189.

(Tóbi Luca dr., Budapest, Pf. 2.; 1428 e-mail: drtobiluca@gmail.com)

A cikk a Creative Commons Attribution 4.0 International License (https://creativecommons.org/licenses/by/4.0/) feltételei szerint publikált Open Access közlemény. (SID_1) 